\title{
Amphiphiles with Polypeptide-Head Groups III. Regulation of Enantioselectivity in Micellar Hydrolysis
}

\author{
Hirotaka IHARA, Toshio IDE, Osamu HotTA, \\ Hakaru UCHIO, ${ }^{\dagger}$ Chuichi HIRAYAMA, \\ and Kimiho YAMADA* \\ Department of Synthetic Chemistry, Faculty of Engineering, and \\ ${ }^{\dagger}$ Education, Kumamoto University, Kumamoto 860, Japan
}

(Received October 7, 1985)

\begin{abstract}
Chiral ester cleavage by achiral hydroxamic acids was investigated in the presence of chiral matrix micelles formed from amphiphiles with poly-L-lysine-head groups. The results are summarized as follows. (1) The enantioselectivity was not observed in the alkaline hydrolysis in chiral micelles only. This matrix possesses no selectivity. When an achiral hydroxamic acid was added to the system, selectivity was induced. (2) The direction of selectivity is reversed by the conformational change of the secondary structure formed by the peptide moiety of matrix micelles. L-Selectivity in the random coil and D-selectivity in the $\alpha$-helix condition were observed. (3) The degree of selectivity is dependent on the chemical structure of hydroxamic acid; for example, an $\mathrm{N}-\mathrm{H}$ type hydroxamic acid gives higher selectivity than an $\mathrm{N}$-methyl type one. Thus, it is supposed that enantioselectivity is introduced by the chiral interaction between chiral micelles and achiral nucleophiles, in which the conformation of polypeptide moiety plays an important role.
\end{abstract}

KEY WORDS Amphiphile / Surfactant / Micelle / Enzyme Model /

Hydroxamate / Enantioselectivity / Polypeptide / Poly-L-lysine / $\alpha$-Helix /

Random Coil /

Many hydrolysis reactions of chiral esters catalyzed by amino acid-derivatives have been studied in micellar systems in order to mimic the enantioselectivity of enzyme reactions. ${ }^{1-3}$ These studies have proposed or proved that the structural fitting between a catalyst and a substrate is a significant factor to give high enantioselectivity. However, in spite of the recognition that the secondary structure of an enzyme plays a part in the specificity, the relation between the secondary structures and enantioselectivity is not yet clear. On the other hand, we investigated the property of chiral assemblies formed from amphiphiles with polypeptide-head groups. It was previously reported that compounds $\mathbf{1 a - 1 d}$ can form micelles with structural asymmetries such as $\alpha$ helical ${ }^{4}$ and $\beta$-sheet peptide-head groups, ${ }^{5}$ and 2 can form helical superstructures composed of single-walled bilayer membranes. ${ }^{6}$

$$
\begin{array}{ccc}
\mathrm{H}-(\mathrm{HN}-\mathrm{CH}-\mathrm{CO})_{n}-(\mathrm{HN}-\mathrm{CH}-\mathrm{CO})_{m}-\mathrm{NH}- \\
\left(\mathrm{CH}_{2}\right)_{4} & \mathrm{R} & \left(\mathrm{CH}_{2}\right)_{15} \mathrm{CH}_{3} \\
\mathrm{NH}_{2} & &
\end{array}
$$

1a: $\mathrm{R}=\left(\mathrm{CH}_{2}\right)_{4} \mathrm{NH}_{2} \quad(m+n=3,8,13$ and 18)

1b: $=\mathrm{CH}_{3} \quad(m=1, n=10)$

1c: $=\mathrm{CH}_{2} \mathrm{C}_{6} \mathrm{H}_{5} \quad(m=1, n=12)$

1d: $=\mathrm{CH}_{2} \mathrm{CH}\left(\mathrm{CH}_{3}\right)_{2}(m=9, n=9)$

\footnotetext{
* To whom correspondence should be addressed.
} 


\section{$\mathrm{H}-(\mathrm{HN}-\mathrm{CH}-\mathrm{CO})_{n}-\mathrm{NH}-\mathrm{CH}-\mathrm{CONH}-\left(\mathrm{CH}_{2}\right)_{11} \mathrm{CH}_{3}$ $\left(\mathrm{CH}_{2}\right)_{2} \quad \mathrm{CH}_{2}$ $\mathrm{COOH} \quad \mathrm{CH}_{2} \mathrm{CONH}-\left(\mathrm{CH}_{2}\right)_{11} \mathrm{CH}_{3}$}

In this study, the effects of chiral matrix micelles on cleavage reactions of chiral esters were investigated, using these polypeptide amphiphiles. As nucleophiles, hydroxamic acids $3 \mathbf{a}-\mathbf{3} \mathbf{c}$ were used. The use of these achiral nucleophiles made the chiral effects from matrix micelles clear.

$$
\begin{aligned}
& \text { 3a: } \quad \mathrm{CH}_{3}\left(\mathrm{CH}_{2}\right)_{8}-\left.{ }_{\mathrm{O}}^{\mathrm{C}-\mathrm{N}}\right|_{\mathrm{OH}} ^{\mathrm{H}} \\
& \text { 3b: } \quad \mathrm{CH}_{3}\left(\mathrm{CH}_{2}\right)_{8}-\left.\underset{\mathrm{O}}{\mathrm{C}-\mathrm{N}}\right|_{\mathrm{OH}} ^{/ \mathrm{CH}_{3}}
\end{aligned}
$$

\section{EXPERIMENTAL}

All amphiphiles were synthesized by the polymerization of $\mathrm{N}$-carboxyanhydride of $\mathrm{N}$ carbobenzoxy-L-lysine with corresponding single-chain alkyl amines as initiators. ${ }^{4,6}$ Hydroxamic acids ${ }^{1}$ and substrates ${ }^{2}$ used were prepared by the previous procedures. The structures were confirmed by NMR and IR spectra and elemental analysis.

CD spectra of amphiphiles 1a-1d in aqueous solutions were measured at $25.0 \pm 0.1^{\circ} \mathrm{C}$ and $\mathrm{pH} 7.2 \pm 0.1$, using a JASCO J-500C spectrophotometer. The concentration of amphiphiles was $4.0 \times 10^{-3} \mathrm{~mol} \mathrm{dm}^{-3}$, and quartz cells having path length from $1 \mathrm{~mm}$ to $0.1 \mathrm{~mm}$ were used.

Ester cleavage was carried out at 25.0 $\pm 0.1^{\circ} \mathrm{C}$ and a range of $\mathrm{pH} 7.0$ to 8.5 in the presence of $\mathrm{NaClO}_{4}\left(0-1.0 \mathrm{~mol} \mathrm{dm}^{-3}\right)$ or $\mathrm{NaCl}\left(0-0.2 \mathrm{~mol} \mathrm{dm}^{-3}\right)$, and was spectrophotometrically followed using the absorption of the product ( $p$-nitrophenolate anion, $\lambda_{\max }$ $400 \mathrm{~nm}$ ). The pseudo-first-order rate constant ( $k_{\mathrm{L}}$ and $k_{\mathrm{D}}$, where $\mathrm{L}$ or $\mathrm{D}$ stands for the chirality of the substrate used) attributable to hydroxamic acids was evaluated from $k_{\text {total }}$ in the presence of hydroxamic acids and $k_{\text {spont }}$ in the absence of hydroxamic acids in the usual way.

$$
k_{\mathrm{L}} \text { or } k_{\mathrm{D}}=k_{\text {total }}-k_{\text {spont }}
$$

Enantioselectivity was expressed by the ratio of $k_{\mathrm{L}}$ to $k_{\mathrm{D}}$ in this study.

\section{RESULTS AND DISCUSSION}

\section{Conformation of Peptide-Head Groups in Mi-} celles

Amphiphiles with poly-L-lysine-head groups (1a-1d) have the cmc of typical surfactants. The micelles are cationic at $\mathrm{pH} 7.0-8.5$, because $\mathrm{pKa}$ of the lysine residue is 9.7 to $10.0 .^{4}$ The cmc values are in the range of 2.0 to $0.5 \times 10^{-3} \mathrm{~mol} \mathrm{dm}^{-3}$ in aqueous solution at $\mathrm{pH}$ 7.2. It was confirmed that the $\mathrm{cmc}$ was lowered by more than a factor of 10 in the presence of more than $0.2 \mathrm{~mol} \mathrm{dm}^{-3}$ of $\mathrm{NaCl}$ or $\mathrm{NaClO}_{4}$. The hydrolysis reaction of chiral esters is carried out in the presence of these additional ions which are used to regulate the conformation of polypeptide-head groups and suppress the contribution of spontaneous hydrolysis by adjusting ionic strength.

Conformation of the poly-L-lysine moiety in these micelles was investigated by the $C D$ method. The spectrum shown by the dotted 
Amphiphiles with Polypeptide-Head Groups III.

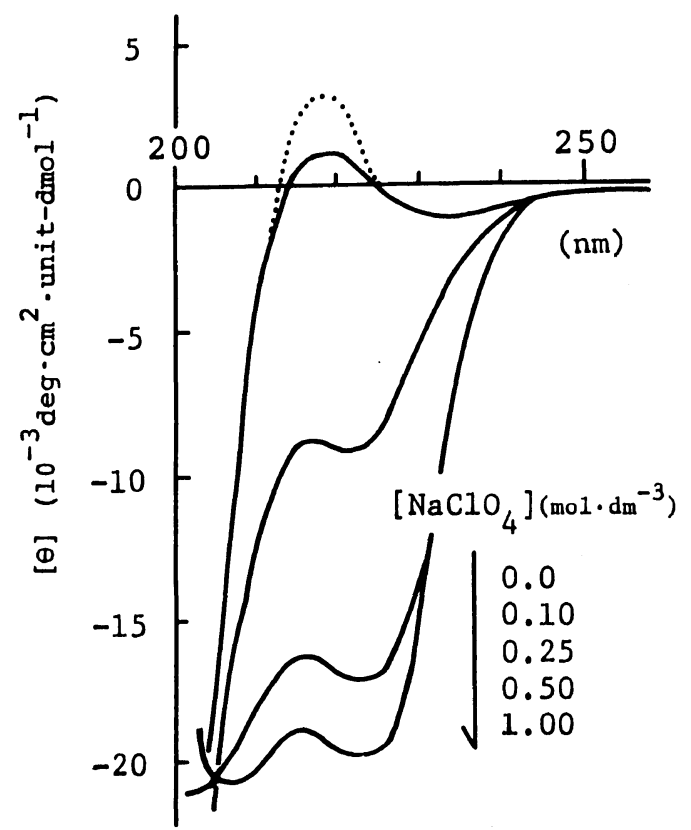

Figure 1. CD spectra of amphiphile 1a $(n=13)$ in the presence of $\mathrm{NaClO}_{4}$. 1a: $4.0 \mathrm{moldm}{ }^{-3}, 25.0^{\circ} \mathrm{C}$, pH 7.2. line in Figure 1 indicates that the conformation of amphiphile 1a is a random coil at $\mathrm{pH}$ 7.2 and $4.0 \times 10^{-3} \mathrm{~mol} \mathrm{dm}^{-3}$ (above cmc). The CD pattern changed from that of the random coil to $\alpha$-helix by the addition of $\mathrm{NaClO}_{4}$ (solid lines in Figure 1). The induction of $\alpha$-helix is attributed to lowering of the electrostatic repulsion among the lysine residues $\left(-\mathrm{NH}_{3}^{+}\right)$by salt formation with $\mathrm{ClO}_{4}^{-} .^{-7}$ On the contrary, strong electrolytes such as $\mathrm{NaCl}$ and $\mathrm{KCl}$ do not induce the conformational change. The relationship between the helix-formation and concentration of $\mathrm{NaClO}_{4}$ is shown in Figure $3 \mathrm{~b}$. The apparent helix content $\left(x^{\mathrm{H}} \%\right)$ was evaluated from the value of $[\theta]_{222}$. The value of $x^{\mathrm{H}}$ reaches saturation by the addition of $0.8-1.0 \mathrm{~mol} \mathrm{dm}^{-3}$ of $\mathrm{NaClO}_{4}$. The saturation in the helical content $\left(x_{\max }^{\mathrm{H}}\right)$ is related to the degree of polymerization $(n)$ in peptide amphiphiles. Figure 2 shows the relation-

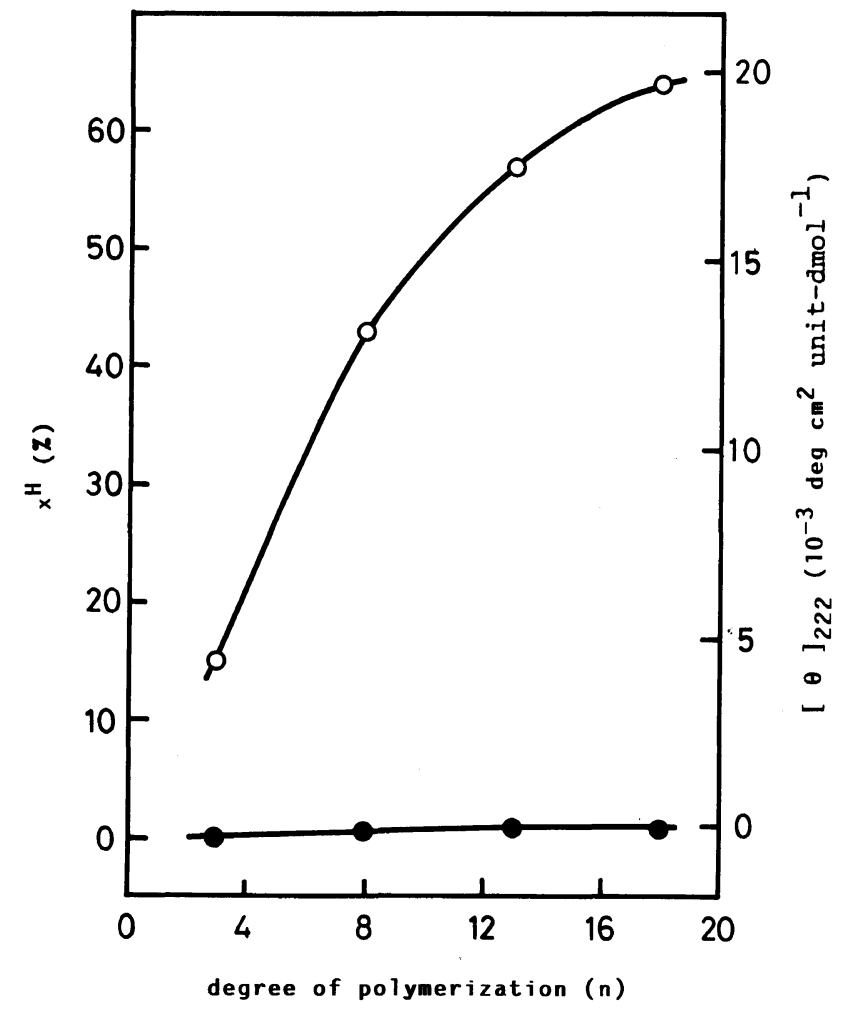

Figure 2. Relationship between helicity $\left(x^{\mathrm{H}}\right)$ and the degree of polymerization $(n)$ of amphiphile 1a. 1a: $4.0 \mathrm{mmol} \mathrm{dm}^{-3}, 25.0^{\circ} \mathrm{C}, \mathrm{pH} 7.2-\mathrm{O}-, 1.0 \mathrm{M}-\mathrm{NaClO}_{4} ;-\bigcirc-, 0.2 \mathrm{M}-\mathrm{NaCl}$. 
Table I. Conformation of polypeptide-head groups in micelles ${ }^{\mathrm{a}}$

\begin{tabular}{ccl}
\hline \multirow{2}{*}{ Amphiphile } & \multicolumn{2}{c}{ Conformation of head-groups } \\
\cline { 2 - 3 } & $0.2 \mathrm{M}-\mathrm{NaCl}$ & $1.0 \mathrm{M}-\mathrm{NaClO}_{4}$ \\
\hline 1a & Random & Helical \\
1b & Random & Helical \\
1c & Random & Helical \\
1d & Helical & Insoluble \\
\hline
\end{tabular}

a $25.0^{\circ} \mathrm{C}, \mathrm{pH}$ 7.2. Amphiphile, above cmc.

ship between the helix content $\left(x_{\max }^{\mathrm{H}}\right)$ and degree of polymerization ( $n$ ) of amphiphile 1a. It is known that the degree of helix-formation in oligopeptides is dependent on that of polymerization $(n) .^{4,8}$ The transition from a random coil to $\alpha$-helix by the addition of $\mathrm{NaClO}_{4}$ was similarly induced in the case of amphiphiles $\mathbf{1 b}$ and 1c. On the other hand, in amphiphile 1d, the $\alpha$-helix form $\left([\theta]_{200},-18000\right.$; $[\theta]_{218},-10000$ at $\left.\mathrm{pH} 7.2\right)$ is partially present even in the absence of $\mathrm{NaClO}_{4}$. It is reported that poly-L-leucine $\left(\mathrm{R}=\mathrm{CH}_{2} \mathrm{CH}\left(\mathrm{CH}_{3}\right)_{2}\right.$ in 1d) can maintain the $\alpha$-helix form because of its hydrophobicity. ${ }^{9}$

It is very significant that the conformational change similar to usual poly-L-lysine is observed even in the micelle formation. On the basis of $\mathrm{CD}$ measurements, the conformation of peptide-head groups in micelles can be summarized approximately as in Table I.

\section{Ester Cleavage}

It is already confirmed that the micelles of amphiphile 1a show a typical saturated kinetic pattern similar to an enzyme reaction toward the hydrolysis of esters $\mathbf{4}$ and $\mathbf{5}$ in the range of pH $9-12 .^{4}$

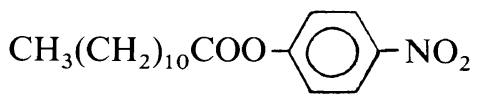

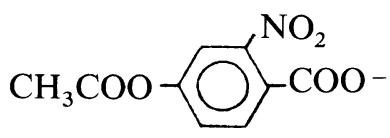

5

In this case, esters $\mathbf{4}$ and $\mathbf{5}$ are bound to cationic peptide micelles (ionized partially) by hydrophobic and electrostatic interactions, respectively, and are hydrolyzed by concentrated $\mathrm{OH}^{-}$and neutral amino groups of lysine residues. ${ }^{4}$

In this study, the cleavage of chiral esters (L$\mathbf{S}$ and D-S) was examined in mixed micellar systems with achiral hydrophobic hydroxamic acids, $\mathbf{3 a}-\mathbf{3} \mathbf{c}$, and the matrix micelles formed from poly-L-lysine amphiphiles, 1a-1d. The $\mathrm{pH}$ of the solution was adjusted to $7.0-8.5$ in order to lessen the contribution of $\mathrm{OH}^{-}$and neutral amino groups of lysine residues as much as possible. The hydroxamate anion, a well known reagent for enzyme model reaction, is highly nucleophilic in the presence of cationic micelles ${ }^{10}$ and has no selectivity for cleavage of chiral esters in non-micellar solutions. ${ }^{1}$ By the use of these achiral nucleophiles, the effects of matrix asymmetries due to $\alpha$ helix and a random coil on enantioselectivity were investigated.

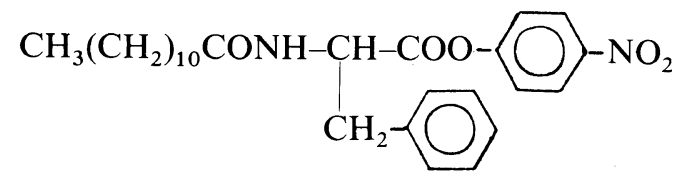

\section{L-S, D-S}

Hydrolysis reaction was carried out in the presence of $\mathrm{NaCl}$ when $\mathrm{NaClO}_{4}$ was not added to the system. Additional $\mathrm{NaCl}$ was used to regulate the hydrolysis rate without conformational change of the polypeptide-head groups. The concentration of $\mathrm{NaCl}$ in the system was adjusted to $0.2 \mathrm{~mol} \mathrm{dm}^{-3}$ because of precipitation at more than $0.3 \mathrm{moldm}^{-3}$. First order rate constants observed in the 
Amphiphiles with Polypeptide-Head Groups III.

Table II. First-order rate constant $\left(k_{\text {spont }}\right)$ and enantioselectivity $\left(k_{\mathrm{L}} / k_{\mathrm{D}}\right)$ in alkaline hydrolysis ${ }^{\mathbf{a}}$

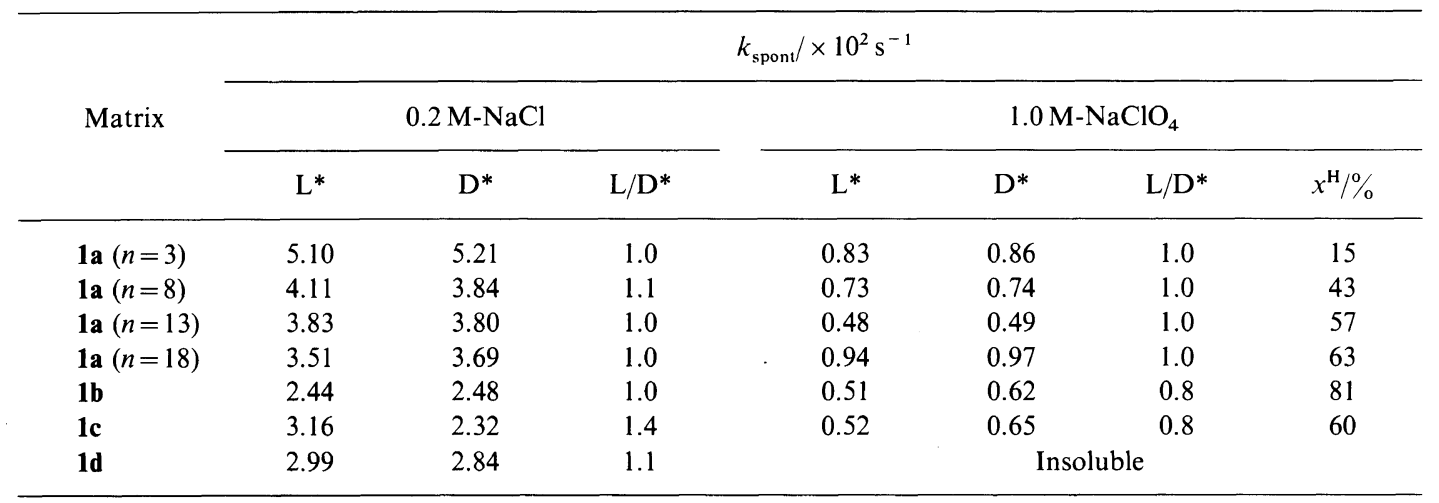

a $x^{\mathrm{H}}$, the content of helix $(\%), 25.0^{\circ} \mathrm{C}, \mathrm{pH} 7.2$; amphiphile, $4.0 \mathrm{mmol} \mathrm{dm}^{-3}$; substrate, $0.04 \mathrm{mmol} \mathrm{dm}^{-3}$.

* $\mathrm{L}$ and $\mathrm{D}$ stand for the chirality of the substrate used.

Table III. First-order rate constant $\left(k_{\mathrm{L}}\right.$ or $\left.k_{\mathrm{D}}\right)$ and enantioselectivity $\left(k_{\mathrm{L}} / k_{\mathrm{D}}\right)$ in the presence of $3 \mathbf{a}^{\mathbf{a}}$

\begin{tabular}{|c|c|c|c|c|c|c|c|}
\hline \multirow{3}{*}{ Matrix } & \multicolumn{7}{|c|}{ First-order rate constant $/ \times 10^{2} \mathrm{~s}^{-1}$} \\
\hline & \multicolumn{3}{|c|}{$0.2 \mathrm{M}-\mathrm{NaCl}$} & \multicolumn{4}{|c|}{$1.0 \mathrm{M}-\mathrm{NaClO}_{4}$} \\
\hline & $\mathrm{L}$ & $\mathrm{D}$ & $\mathrm{L} / \mathrm{D}$ & $\mathrm{L}$ & $\mathrm{D}$ & $\mathrm{L} / \mathrm{D}$ & $x^{\mathrm{H}} / \%$ \\
\hline $1 \mathbf{a}(n=3)$ & 3.04 & 2.21 & 1.4 & 2.17 & 2.33 & 0.9 & 15 \\
\hline $1 \mathbf{a}(n=8)$ & 3.12 & 1.49 & 2.1 & 1.17 & 1.65 & 0.7 & 43 \\
\hline 1a $(n=13)$ & 7.83 & 3.40 & 2.3 & 1.15 & 1.57 & 0.7 & 57 \\
\hline 1a $(n=18)$ & 5.38 & 2.43 & 2.4 & 1.37 & 1.92 & 0.7 & 63 \\
\hline 1b & 5.38 & 1.69 & 3.2 & 1.98 & 1.63 & 1.2 & 81 \\
\hline 1c & 6.64 & 2.52 & 3.6 & 1.21 & 0.60 & 2.0 & 60 \\
\hline 1d & 7.26 & 7.20 & 1.0 & \multicolumn{4}{|c|}{ Insoluble } \\
\hline
\end{tabular}

a $25.0^{\circ} \mathrm{C}$, pH 7.2. Amphiphile, $4.0 \mathrm{mmol} \mathrm{dm}^{-3}$; 3a, $0.4 \mathrm{mmol} \mathrm{dm}^{-3}$; substrate, $0.04 \mathrm{mmol} \mathrm{dm}^{-3}$.

chiral ester cleavage are summarized in Tables II and III.

In the absence of $\mathbf{3 a}$, no enantioselectivity was observed regardless of conformational change of matrix micelles $\left(\mathrm{L} / \mathrm{D}=1\right.$ in $k_{\text {spont }}$ as shown in Table II). The chirality of matrix seems to play no role. It is presumed that the ester is hydrolyzed by $\mathrm{OH}^{-}$concenteated onto the micelles, since amino group-residues of amphiphiles are almost completely protonized at $\mathrm{pH} 7.2$.

On the contrary, the selectivity was induced by the addition of hydroxamic acid 3a with increase of $k_{\text {total }}$. The values of $k_{\mathrm{L}}$ and $k_{\mathrm{D}}$ were obtained by subtraction of $k_{\text {spont }}$ from $k_{\text {total }}$ and are shown in Table III. Since 3a is achiral and has no enantioselectivity, it may be considered that the selectivity is introduced by co-operation between the chiral micelles and achiral nucleophiles. We cannot explain this mechanism, although many speculations for the mechanism of enantioselectivity have been suggested in various micellar systems. ${ }^{3}$ However, it could be supposed from the following results that the secondary structural asymmetry introduced from the poly-L-lysine moiety is important for enantioselectivity. First, the selectivity for L-S and D-S was changed 


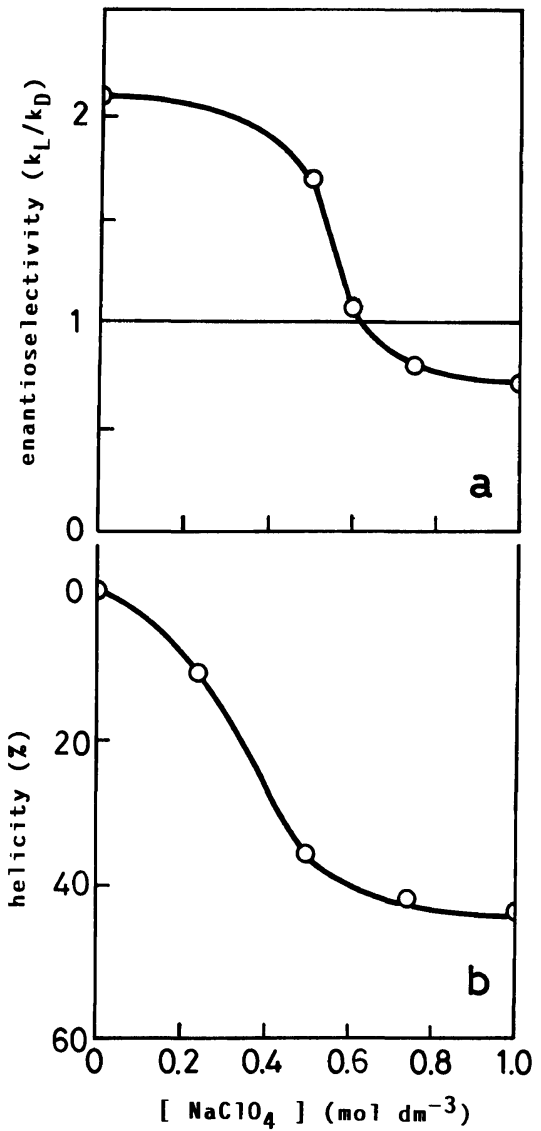

Figure 3. Relationship between the concentration of $\mathrm{NaClO}_{4}$ and selectivity (a) or helicity (b) at $25.0^{\circ} \mathrm{C}, \mathrm{pH}$ 7.2 (a) 1a: $4.0 \mathrm{mmol} \mathrm{dm}^{-3}$ with $3 \mathrm{a}: 0.4 \mathrm{mmol} \mathrm{dm}^{-3}$ (b) 1a: $4.0 \mathrm{mmol} \mathrm{dm}^{-3}$.

by the addition of $\mathrm{NaClO}_{4}$. For example, the value of $k_{\mathrm{L}} / k_{\mathrm{D}}$ changed from 2.4 to 0.7 in the case of amphiphile 1a $(n=18)$. As shown in Figure 3, the selectivity change is related to the conformational change from a random coil to $\alpha$-helix upon the addition of $\mathrm{NaClO}_{4}$. A similar result is obtained in the addition of poly(acrylic acid). The presence of poly(acrylic acid) promotes the helix-formation of amphiphile 1a and causes the selectivity change. The content of helix increased from 0 to $80 \%$ and $k_{\mathrm{L}} / k_{\mathrm{D}}$ changed from 2.4 to 0.6 by the addition of $0.25 \mathrm{wt} \%$ of poly(acrylic acid) at $\mathrm{pH}$ 7.2. Poly(acrylic acid) is also one of the additive ions which causes induction of the
Table IV. Enantioselectivity of some nucleophiles in the presence of 1a $(n=8)^{\mathrm{a}}$

\begin{tabular}{|c|c|c|c|c|c|c|}
\hline \multirow{3}{*}{ Nucleophile } & \multicolumn{6}{|c|}{ First-order rate constant $/ \times 10^{2} \mathrm{~s}^{-1}$} \\
\hline & \multicolumn{3}{|c|}{$0.2 \mathrm{M}-\mathrm{NaCl}$} & \multicolumn{3}{|c|}{$1.0 \mathrm{M}-\mathrm{NaClO}^{4}$} \\
\hline & $\mathrm{L}$ & $\mathrm{D}$ & $\mathrm{L} / \mathrm{D}$ & $\mathrm{L}$ & $\mathrm{D}$ & $\mathrm{L} / \mathrm{D}$ \\
\hline None & 4.11 & 3.84 & 1.1 & 0.73 & 0.74 & 1.0 \\
\hline $3 \mathbf{a}$ & 3.12 & 1.49 & 2.1 & 1.17 & 1.65 & 0.7 \\
\hline $\mathbf{3 b}$ & 1.49 & 1.04 & 1.4 & 0.91 & 1.08 & 0.8 \\
\hline $3 \mathbf{c}$ & 2.65 & 0.88 & 3.0 & 1.05 & 1.62 & 0.6 \\
\hline
\end{tabular}

helix formation of poly-L-lysine. ${ }^{11}$ Secondly, the selectivity increases with the degree of polymerization $(n)$ of head-groups of the matrix amphiphiles. It is known that the conformation of a low-molecular-weight polypeptide is dependent on $n .^{4,8}$ Thirdly, the enantioselectivity and activity changed by the structural differences of hydroxamates added. This result indicates that the achiral hydroxamate possesses chiral selectivity due to interaction with the chiral matrix. Hydrogen bonding between the hydroxamate and micelles is considered to induce chirality, because the degree of the selectivity is higher in the hydroxamate of $\mathrm{N}-\mathrm{H}$ type than those of $\mathrm{N}$-methyl type, as shown in Table IV. This supposition is not yet proved, since we could not detect the ICD of hydroxamate $3 \mathbf{c}$ by the chiral matrix.

The enantioselectivity $\left(k_{\mathrm{L}} / k_{\mathrm{D}}\right)$ is also sensitive to structural differences of the peptide moiety in matrix amphiphiles. When a spacer such as L-phenylalanine or L-alanine was introduced between the long-chain alkyl group and poly-L-lysine-head group, the ratio of $k_{\mathrm{L}} / k_{\mathrm{D}}$ increased from 2.1 to 3.2 under the random coil condition and changed from $D$ selectivity $\left(k_{\mathrm{L}} / k_{\mathrm{D}}=0.7\right) \quad$ to $\quad$ L-selectivity $\left(k_{\mathrm{L}} / k_{\mathrm{D}}=2.0\right)$ in the $\alpha$-helix condition. The $\mathrm{CD}$ spectra of amphiphiles $\mathbf{1 b}$ and $\mathbf{1 c}$ at $\mathrm{pH} 7.2$ are similar to that of amphiphile $\mathbf{1 a}$. These results indicate that the interaction be- 
tween the matrix and hydroxamate produces at the spacer site varying chiral environments by the introduction of a different amino acid. On the other hand, in the case of 1d by which the block of poly-L-leucine (which forms $\alpha$-helix) was introduced as a spacer, the selectivity disappeared from 2.1 to 1.0 under the random coil condition. Therefore, it is clear that the local chirality based on the structure of the peptide moiety as well as matrix asymmetry plays a part in the enantioselective reaction.

In conclusion, this study provides a typical example of the relation between the secondary structure of polypeptide(s) and enantioselectivity in micellar catalysis. Selectivity is induced by an achiral hydroxamate in the chiral environment and is regulated by conformational change of matrix micelles.

The mode of chiral interaction is still obscure, but we suppose that the reaction site in micelles is near the root of polypeptide-head groups, and the peptide conformation plays an important role in enantioselective reactions.

Acknowledgements. We thank Mr. Fukumoto for his capable experimental assistance. This work was partially supported by a Grantin-Aid for Scientific Research from the Ministry of Education, Science, and Culture of Japan.

\section{REFERENCES}

1. K. Yamada, H. Shosenji, and H. Ihara, Chem. Lett., 491 (1979); K. Yamada, H. Shosenji, H. Ihara, and S. Ono, Tetrahedron Lett., 20, 2592 (1979); H. Ihara, S. Ono, H. Shosenji, and K. Yamada, J. Org. Chem., 45, 1623 (1980).

2. S. Ono, H. Shosenji, and K. Yamada, Tetrahedron Lett., 22, 2371 (1981).

3. K. Ohkubo, K. Sugahara, K. Yoshinaga, and R. Ueoka, J. Chem. Soc., Chem. Commun., 637 (1980); K. Ohkubo, H. Ogata, K. Yamaki, and K. Yamashita, Makromol. Chem., 185, 891 (1984); Y. Ihara, J. Chem. Soc., Chem. Commun., 984 (1978); Y. Ihara, N. Kunikiyo, T. Yunimasa, N. Nango, and Y. Kuroki, Chem. Lett., 667 (1981); R. A. Moss and G. O. Bizzigotto, J. Am. Chem. Soc., 103, 6512 (1981).

4. H. Uchio, H. Ihara, T. Izuno, T. Ide, K. Taniguchi, and K. Yamada, Yukagaku, 33, 38 (1984).

5. K. Yamada, H. Ihara, T. Ide, T. Fukumoto, and C. Hirayama, Chem. Lett., 1731 (1984).

6. H. Ihara, T. Ide, K. Taniguchi, K. Yamada, and H. Uchio, Polym. Prepr. Jpn., 33, 361 (1984).

7. E. Peggion, A. Cossani, M. Tervojecvichi, and G. Borin, Biopolymers., 11, 633 (1972).

8. A. Yaron, E. Katchalski, and A. Berger, Biopolymers., 10, 1107 (1971).

9. E. R. Blout, "Polyamino Acids, Polypeptide, and Proteins," The University of Wisconsin Press, Madison, 1962.

10. T. Kunitake, Y. Okahata, and T. Sakamoto, Chem. Lett., 459 (1975); I. Tabushi, Y. Kuroda, and S. Kita, Tetrahedron Lett., 643 (1974); I. Tabushi and Y. Kuroda, ibid., 3613 (1974).

11. A. B. Zezin, V. V. Lutsenko, V. B. Rogacheva, O. A. Aleksina, R. I. Kalyuzhnaya, V. A. Kavanov, and V. A. Kiargin, Vyskomol. Soedin. Ser., A, 14, 772 (1972). 